\title{
Lumbosacral Transitional Vertebrae: A Case Report and Clinical Implications
}

\author{
Vértebras Lumbosacras de Transición: Reporte de un Caso e Implicancias Clínicas
}

B. V. Murlimanju; Latha V. Prabhu; Mangala M. Pai; Ganeshkumar, C. \& Ankamma Sarvepalli

MURLIMANJU, B. V.; PRABHU, L. V.; PAI, M. M.; GANESHKUMAR, C. \& SARVEPALLI, A. Lumbosacral transitional vertebrae: A case report and clinical implications. Int. J. Morphol., 29(4):1123-1125, 2011.

SUMMARY: A lumbosacral transitional vertebra is a rare congenital anomaly which occurs because of defect in the segmentation of the lumbosacral spine during development. During routine osteology classes for the medical students at the Kasturba Medical College, Mangalore, India, one of the sacra showed the fusion of the fifth lumbar vertebra with the sacrum. The specimen showed an incomplete fusion (sacralization) on the left side and the transverse process was of the large butterfly shape, while on the right it was about the usual size. Though this variation is well known, the details of this anomaly are rarely reported in the anatomical literature. Since there is a strong relationship between the lumbosacral transitional vertebrae and low back pain, this anomaly has gotten increased clinical interest. So this case was studied in detail with relevant review of literature and its surgical, radiological implications are discussed.

KEY WORDS: Back pain; Congenital anomaly; Lumbosacral vertebra; Sacralization; Transitional vertebra.

\section{INTRODUCTION}

Lumbosacral transitional vertebrae (LSTV) are congenital anomalies of the lumbosacral region which includes lumbarization and sacralization (Kim \& Suk, 1997), observed for the first time by Bertolotti (Delport et al., 2006). This condition occurs due to defect in the segmentation of the lumbosacral spine during development (Eyo et al., 2001). The transitional vertebra may have varying formations, the common feature being an atypical lumbosacral articulation between the transverse process of L5 and the sacrum (Kanchan et al., 2009). When the L5 vertebra is fused to the sacrum completely (sacralisation of L5), there are only four lumbar vertebrae, whereas when $\mathrm{S} 1$ is separated from the sacrum (lumbarisation of S1), there are six lumbar vertebrae and many intermediate variations are reported. Complete sacralization consists of a complete bony union between the abnormal transverse process and the sacrum. Incomplete sacralization shows a well defined joint line between the process and the sacrum. Both forms may be either unilateral or bilateral (Moore, 1925). It was reported that there is a strong relationship between the LSTV and low back pain (LBP). It is possible that $\mathrm{L} 5$ sacralization contributes to the development of orthopedic diseases like degenerative spondylolisthesis, lumbar disc degeneration, herniation and low back pain (Kong et al., 2008). Though this variation is well known, most of the reports are from orthopedic literature and that from anatomical view point are not available. Hence this case was studied in detail and its literature was reviewed. This report discusses a case of unilateral lumbosacral transitional vertebra with its surgical and radiological implications.

\section{CASE REPORT}

During routine osteology classes taken for the medical students, we observed one of the sacra showing fusion of the fifth lumbar vertebra with the sacrum (Fig. 1). From the anterior view (Fig. 1A), there was an incomplete sacralization on the left side. The transverse process on this side was large butterfly shaped, while on the right side it was usual size. The sacralized side showed a definite joint apparently of the same type as the sacro-iliac joint. The body of the L5 was distinctly wedge shaped, being thinner on the right side than on the left. There was a slight rotation of this vertebra to the left. The whole right side of the vertebra appeared to have sagged forward somewhat. The sacralized side was more securely anchored than the normal side. The lumbo-sacral angle was somewhat greater than the normal. From the posterior view (Fig. 1B), it was observed that there was a failure of union of the spinous process of the first sacral vertebra. 


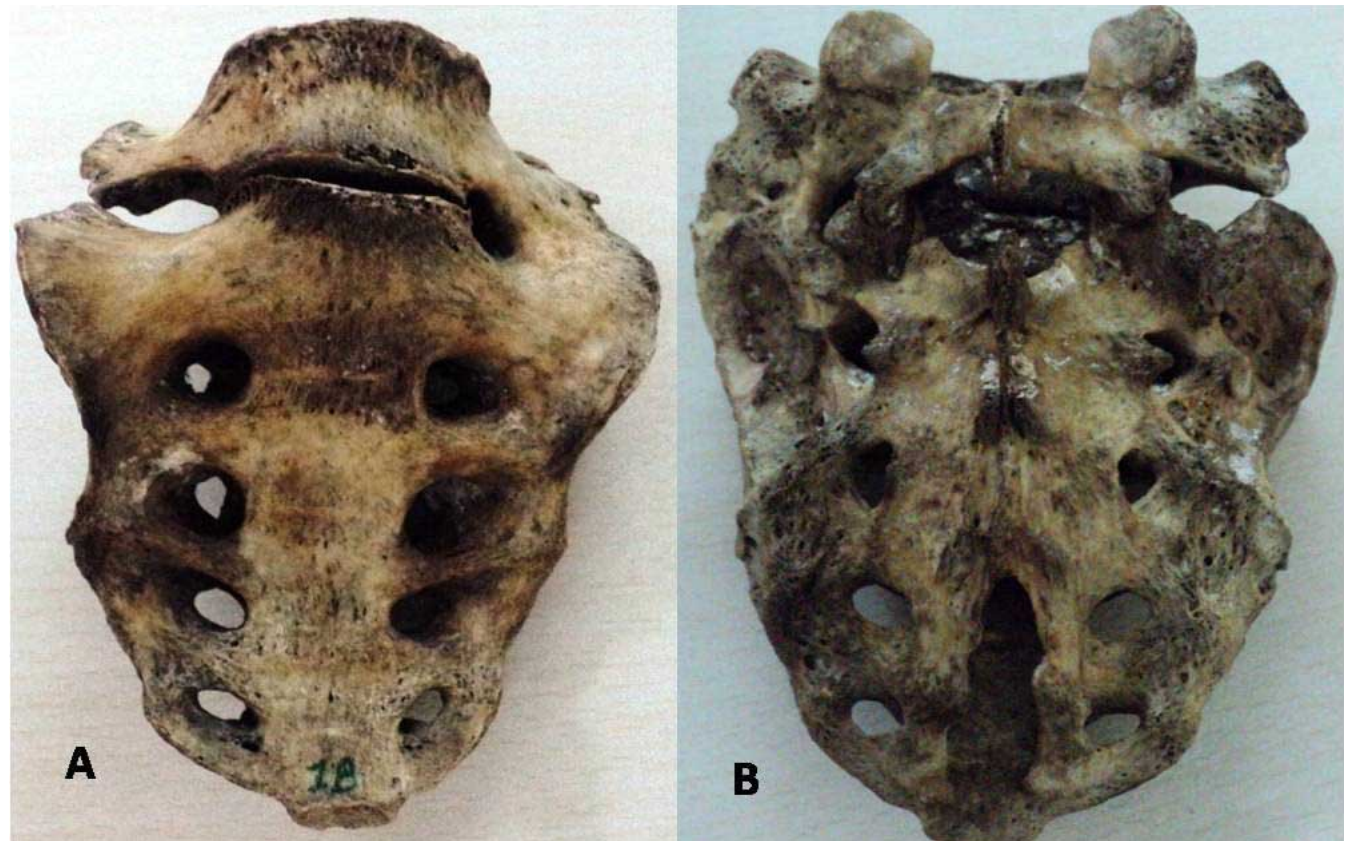

Fig. 1. Photograph showing (A) Anterior and (B) Posterior views of the transitional vertebra.

\section{DISCUSSION}

In the present study, we observed the incomplete fusion of the L5 into the sacrum. The sex of the sacrum was not determined. The incidence of sacralization was reported to be more common in males (Eyo et al.). It was also reported that the $50 \%$ chance of getting low back pain in patients having LSTV (Eyo et al.). A transitional vertebra is a congenital anomaly that has the characteristics of two types of vertebrae. Normally, five sacral vertebrae fuse to form the wedge-shaped sacrum with ossification of the intervertebral joints (Kanchan et al.). Broadest superiorly, the sacrum articulates with the L5 vertebra, while inferiorly, it narrows to articulate with the coccyx. The first sacral vertebra may not fuse with the second, in which case there is lumbarization of $\mathrm{S} 1$ and the person appears to have six lumbar vertebrae. The converse can also occur, called sacralization of L5, where the individual appears to have four lumbar vertebrae (Hambly et al., 1998). The condition is more often bilateral and reported to have medicolegal and clinical implications (Kanchan et al.). The incidence of this anomaly vary greatly, ranging from $4 \%$ to $24 \%$ (Delport et $a l$.) and is clinically very well debated. The LSTV resulting in overwork at that joint can cause arthritis, disc changes or spinal cord compression. The person is usually asymptomatic or may present with symptoms which include spinal or radicular pain, disc degeneration, L4/L5 disc prolapse, lumbar scoliosis and lumbar extradural defects (Willaims et al., 1989; Hsieh et al., 2000).
In LSTV, the transition involves either the fifth lumbar vertebra (sacralization) or the first sacral vertebra (lumbarization). Lumbarization means either complete or incomplete fusion of the upper sacral vertebrae to the L5 and sacralization is either complete or incomplete fusion of L5 to the top of the sacrum (Eyo et al.). The incidence ratio of sacralization to lumbarization was reported as 2:1 (Eyo et al.). In transitional lumbosacral segmentation, it was observed that the lumbosacral intervertebral disc is significantly narrowed (Tini et al., 1977; Ebraheim et al., 1997; Revuelta et al., 2000), the incidence of disc herniation is found to be higher and can occur even at young ages (Williams, 1965; Otani et al., 2001). There was also relationship established between transitional vertebrae and the degree of slippage in spondylolytic spondylolisthesis (Kim \& Suk; Cinotti et al., 1997). In addition, this anomaly has known implications in the field of disc surgery. There are reports of surgery being performed at the wrong lumbar level (Wiese et al., 2004) and the presence of a transitional vertebra may contribute to this error. During medicolegal investigations, some congenital abnormalities are of vital importance in identification, especially when antemortem records are available (Kanchan et al.). A person with lumbosacral transitional vertebra is likely to seek medical advice if the condition is symptomatic and thus there is a high chance that antemortem medical records exist. From the medicolegal perspective, this has implications for the determination of primary indicators of identification. Thus, 
when skeletal remains are brought in for examination, the transitional vertebra can be helpful in confirming identity (Kanchan et al.). We believe that, awareness of this kind of anomalies is of importance while reporting the $\mathrm{X}$ ray, $\mathrm{CT}$ and MRI films, during surgical procedures at the lumbosacral region and making a differential diagnosis for the lowback ache patients. Its knowledge is not only enlightening for the orthopaedic surgeons, also vital for the clinical anatomists, forensic experts and morphologists. Hence we are reporting one such variation with emphasize on its clinical relevance.

MURlimanJU, B. V.; PRABHU, L. V.; PAI, M. M.; GANESHKUMAR, C. \& SARVEPALLI, A. Vértebras lumbosacras de transición: Reporte de un caso e implicancias clínicas. Int. J. Morphol., 29(4):1123-1125, 2011.

RESUMEN: Una vértebra de transición lumbosacra es una anomalía congénita rara que se produce debido a defectos en la segmentación de la columna lumbosacra durante el desarrollo. Durante una clase de osteología para estudiantes de medicina en Kasturba Medical College, Mangalore, India, una de las regiones sacras mostró fusión de la quinta vértebra lumbar con el sacro. El especimen mostró fusión incompleta (sacralización) en el lado izquierdo y el proceso transverso tenía forma de mariposa grande, mientras que en el derecho se observó de tamaño normal. A pesar que esta variación es conocida, los detalles de esta anomalía rara vez son reportados en la literatura anatómica. Puesto que existe una fuerte relación entre las vértebras de transición lumbosacra y el dolor de espalda baja, esta anomalía tiene gran interés clínico. Este caso fue estudiado en detalle con la revisión pertinente de la literatura, y son discutidas sus implicancias quirúrgicas y radiológicas.

PALABRAS CLAVE: Dolor de espalda; Anomalía congénita; Vértebra lumbosacra; Sacralización; Vértebra de transición.

\section{REFERENCES}

Cinotti, G.; Postacchini, F.; Fassari, F. \& Urso, S. Predisposing factors in degenerative spondylisthesis. A radiographic and CT study. Int. Orthop., 21(5):337-42, 1997.

Delport, E. G.; Cucuzzella, T. R.; Kim, N.; Marley, J.; Pruitt, C. \& Delport, A. G. Lumbosacral transitional vertebrae: incidence in a consecutive patient series. Pain Physician., 9(1):53-6, 2006.

Ebraheim, N. A.; Miller, R. M.; Xu, R. \& Yeasting, R. A. The location of the intervertebral lumbar disc on the posterior aspect of the spine. Surg. Neurol., 48(3):232-6, 1997.

Eyo, M. U.; Olofin, A.; Noronha, C. \& Okanlawon, A. Incidence of lumbosacral transitional vertebrae in low back pain patients. West African Journal of Radiology, 8(1):1-6, 2001.

Hambly, M. F.; Wiltse, L. L.; Raghavan, N.; Schneiderman, G. \& Koenig, C. The transition zone above a lumbosacral fusion. Spine, 23(16):1785-92, 1998.

Hsieh, C. Y.; Vanderford, J. D.; Moreau, S .R. \& Prong, T. Lumbosacral transitional segments: classification, prevalence and effect on disc height. J. Manipulative Physiol. Ther., 23(7):483-9, 2000.

Kanchan, T.; Shetty, M.; Nagesh, K. R. \& Menezes, R. G. Lumbosacral transitional vertebra: clinical and forensic implications. Singapore Med. J., 50(2):e85-7, 2009.

Kim, N. H. \& Suk, K. S. The role of transitional vertebrae in spondylolysis and spondylolytic spondylolisthesis. Bull. Hosp. Jt. Dis., 56(3):161-6, 1997.

Kong, C. G.; Park, J. S. \& Park, J. B. Sacralization of L5 in Radiological Studies of Degenerative Spondylolisthesis at L4L5. Asian Spine J., 2(1):34-7, 2008.
Moore, B. H. Sacralization of the fifth lumbar vertebra. J. Bone Joint Surg. Am., 7:271-8, 1925.

Otani, K.; Konno, S. \& Kikuchi, S. Lumbosacral transitional vertebra and nerve root symptoms. J. Bone Joint Surg. Br., 83(8):1137-40, 2001.

Revuelta, R.; De Juambelz, P. P.; Fernandez, B. \& Flores, J. A. Lumbar disc herniation in a 27 -month old child. Case report. J. Neurosurg., 92(1):98-100, 2000.

Tini, P. G.; Wieser, C. \& Zinn, W. M. The transitional vertebra of the lumbosacral spine: its radiological classification, incidence, prevalence and clinical significance. Rheumatol. Rehabil., 16(3):180-5, 1977.

Wiese, M; Krämer, J.; Bernsmann, K. \& Ernst Willburger, R. The related outcome and complication rate in primary lumbar microscopic disc surgery depending on the surgeon's experience: comparative studies. Spine J., 4(5):550-6, 2004.

Williams, P. C. The lumbosacral spine, emphasizing conservative management. New York, McGraw-Hill Book Company, 1965. pp.27-32, 149-50.

Williams, P. L.; Warwick, R.; Dyson, M. \& Bannister, L. H. Gray's Anatomy. $37^{\text {th }}$ ed. New York, ELBS-Churchill Livingstone, 1989.

Correspondence to:

B. V. Murlimanju, MD.

Assistant Professor, Department of Anatomy

Kasturba Medical College, Manipal University

Mangalore - 575004

INDIA

Email: flutesnowmm@gmail.com

Received: 03-11-2010

Accepted: 08-07-2011 